\title{
KAJIAN PENGARUH PERLAKUAN PULP DAN LAMA PENYEDUHAN TERHADAP MUTU KIMIA TEH CASCARA
}

\author{
Murna Muzaifa, Dian Hasni, Normalina Arpi, M. Ikhsan Sulaiman, Moh. Sahlan Limbong \\ Jurusan Teknologi Hasil Pertanian, Fakultas Pertanian Universitas Syiah Kuala Darussalam Banda Aceh 23111 \\ Email Koresponden: murnamuzaifa@unsyiah.ac.id
}

\begin{abstract}
ABSTRAK
Telah dilakukan penelitian untuk menganalisis mutu kimia seduhan cascara yang diperoleh dari kulit kopi arabika Gayo. Penelitian ini menggunakan rancangan acak lengkap dengan dua faktor yaitu perlakuan pulp dan lama seduhan cascara. Faktor perlakuan pulp kopi (P) terdiri atas 6 taraf yaitu pulp buah kopi yang difermentasi dalam karung selama 12 jam $\left(\mathrm{P}_{1}\right)$, pulp yang direndam air selama 12 jam $\left(\mathrm{P}_{2}\right)$, pulp yang dibiarkan diruang terbuka $\left(\mathrm{P}_{3}\right)$, pulp dari pengolahan kering $\left(\mathrm{P}_{4}\right)$, pulp dari limbah produksi wine coffee $\left(\mathrm{P}_{5}\right)$ dan pulp dari limbah petani $\left(\mathrm{P}_{6}\right)$. Faktor kedua yaitu lama penyeduhan $(\mathrm{H})$ yang terdiri atas 3 taraf yaitu $\left(\mathrm{H}_{1}=4\right.$ menit, $\mathrm{H}_{2}=6$ menit dan $\mathrm{H}_{3}=8$ menit). Parameter yang diamati meliputi nilai $\mathrm{pH}$, total padatan terlarut dan total fenol. Hasil penelitian menunjukkan bahwa perlakuan pulp kopi dan lama seduhan berpengaruh terhadap nilai $\mathrm{pH}$ dan total padatan terlarut. Nilai total fenol seduhan cascara hanya dipengaruhi oleh lama penyeduhan cascara. Cascara dengan total fenol tertinggi diperoleh pada pembuatan cascara dari pulp secara natural dengan penyeduhan 8 menit.
\end{abstract}

Kata kunci-arabika gayo; cascara; fermentasi; pulp; seduhan

\section{PENDAHULUAN}

Indonesia merupakan negara penghasil kopi terbesar keempat didunia, setelah Brazil, Vietnam dan kolombia. Jenis kopi yang ditanam di Indonesia umumnya adalah kopi robusta dan arabika. Luas areal lahan perkebunan kopi Indonesia mencapai 1.227.728 ha dengan produksi kopi 637.539 ton. Wilayah paling tinggi produksi kopi di Indonesia adalah provinsi Sumatra Selatan yang memiliki luas areal 250.171 Ha dengan 11.048 ton produk kopi robusta (Dirjen Perkebunan, 2017). Khususnya kopi arabika, Aceh merupakan salah satu provinsi penghasil kopi arabika terbesar di Indonesia. Menurut data BPS (2016), produksi kopi arabika sekitar 47.378 ton dengan luas areal mencapai $121.060 \mathrm{Ha}$.

Kopi umumnya diperdagangkan dalam bentuk biji yang diperoleh melalui sejumlah tahapan pengolahan untuk memisahkannya dari bagian non biji. Bagian non biji inilah yang menjadi limbah dalam pengolahan kopi. Dapat berupa pulp (kulit buah kopi segar), lendir, husk (kulit tanduk) dan kulit ari (Mussatto et al., 2011; Berlitz et al., 2009; Esquivel dan Jimenez, 2012). Jumlah produksi kopi yang tinggi tentunya menghasilkan limbah kopi yang tinggi juga. Sejauh ini limbah buah kopi belum dimanfaatkan secara optimal oleh masyarakat Indonesia. Penggunaan limbah kopi oleh petani hanya sebatas untuk pupuk dan pakan ternak.

Pulp merupakan limbah kopi terbesar, mencapai 40- 50\%. Esquivel (2011) menyebutkan bahwa limbah pulp kopi memiliki komposisi seperti karbohidrat (35\%), protein $10 \%$, fiber $(30,8 \%)$ dan mineral $(10,7 \%)$, protein $(8,9 \%)$, gula $(4,1 \%)$. Adapun menurut Pandey $(2000)$, pulp kopi dari hasil pulping mengandung sekitar 50\% karbohidrat, $10 \%$ protein, $20 \%$ serat, $2,5 \%$ lemak, dan 1,3\% kafein . Selain itu, limbah pulp ini mengandung senyawa polifenol (asam klorogenat, flavonol, antosianidin, katekin, rutin, tanin dan asam ferulat).

Pulp kopi sebenarnya dapat diolah menjadi produk minuman istimewa (nikmat dan menyehatkan) dengan proses pengolahan yang sangat sederhana namun memiliki potensi ekonomis yang sangat menjanjikan. Produk yang dimaksud adalah cascara, produk ini diluar negeri cukup dikenal dan mempunyai harga jual yang sangat fantastis. Di Indonesia sendiri, khususya Kabupaten Garut Jawa Barat telah mulai memproduksi cascara dan mengekspornya ke Singapura, Hongkong dan Amerika Serikat. Harga cascara di Indonesia dijual Rp. 40.000 perbungkusnya, sementara harga diluar negeri dapat mencapai 70 dolar Amerika (Ghani, 2017). Minuman ini memiliki citarasa khas tersendiri dan memiliki aktivitas antioksidan yang tinggi (Heeger dkk., 2017), dapat diminum tanpa gula karena munculnya rasa manis alami dan citarasa asam segar istimewa yang terdapat pada pulp 
kopi. Namun sayangnya hingga saat ini di Dataran Tinggi Gayo belum banyak yang mengetahui potensi cascara disebabkan masih minimnya pengetahuan masyarakat yang mampu mengolah cascara dan belum adanya standar mutu pembuatan cascara yang baik.

Faktor-faktor utama yang mempengaruhi mutu kopi adalah varietas kopi, letak geografis, ketinggian tempat dan kondisi daerah penanaman, metode pengolahan (fermentasi) dan metode penyimpanan (Baggenstoss, 2008). Metode pengolahan kopi terdiri atas pengolahan basah, kering dan semi basah, ditambah lagi sejumlah cara modifikasi yang dilakukan petani untuk memproduksi kopi spesialti untuk meningkatkan nilai jual kopi (Suroyo, 2014; Muzaifa dan Hasni, 2015; Poltronieri dan Rossi, 2019). Kondisi pengolahan yang berbeda tersebut menghasilkan pulp dengan kondisi yang berbeda. Hal ini tentunya mempengaruhi cascara yang dihasilkan.

Proses penyeduhan cascara menjadi minuman seperti teh juga dapat mempengaruhi kualitas seduhan cascara yang dihasilkan. Penyeduhan diketahui berfungsi untuk mengekstraksi sejumlah komponen kimia penting yang terdapat dalam minuman teh. Hal yang perlu diperhatikan selama proses penyeduhan yaitu suhu air dan lama penyeduhan. Mustika (2016), untuk mengeluarkan citarasa cascara diperlukan waktu penyeduhan selama 4 menit agar. Penggunaan suhu air yang tinggi pada proses penyeduhan mempengaruhi pengekstrakan kandungan kimia yang terdapat pada teh. Lama penyeduhan juga mempengaruhi kadar bahan terlarut, warna dan aroma. Dalam prakteknya, waktu penyeduhan cascara masih bervariasi. Berdasarkan uraian tersebut perlu dilakukan penelitian untuk mengetahui karakteristik seduhan cascara yang diperoleh dari perlakuan pulp dan lama penyeduhan yang berbeda.

\section{METODOLOGI PENELITIAN}

\section{A. Bahan dan Peralatan}

Bahan baku utama yang digunakan dalam penelitian ini adalah buah kopi arabika (berwarna merah ceri) yang diperoleh dari kabupaten Aceh Tengah yang akan diambil pulpnya. Bahan untuk uji kimia yang digunakan yaitu akuades, reagen follin ciocalteu, $\mathrm{Na}_{2} \mathrm{CO}_{3} 5 \%$ dan etanol $95 \%$. Bahan uji sensoris yang digunakan yaitu crackers dan air mineral.

Peralatan yang digunakan dalam penelitian ini adalah ember, pulper, $\mathrm{pH}$ meter, timbangan analitik, stoples kaca, saringan, sendok, kuvet, terpal, kompor gas, gelas piala, labu erlenmayer, pipet tetes, saringan, tabung reaksi, water bath, spektrofotometer-UV, gelas, kertas kode uji sensori dan form penilaian.

\section{B. Rancangan Penelitian}

Rancangan penelitian ini menggunakan Rancangan Acak Kelompok (RAK) dengan dua faktor, yaitu perlakuan pulp kopi (P) yang terdiri atas 6 taraf perlakuan yaitu pulp buah kopi yang difermentasi dalam karung selama 12 jam (P1), pulp yang direndam air selama 12 jam (P2), pulp yang dibiarkan diruang terbuka selama 12 jam (P3), pulp dari pengolahan natural (P4), pulp dari limbah produksi wine coffee (P5) dan pulp dari limbah petani (P6) dimana limbah diperoleh dari hasil panen petani. Faktor kedua yaitu lama penyeduhan $(\mathrm{H})$ yang terdiri dari 3 taraf yaitu $\mathrm{H} 1=4$ menit, $\mathrm{H} 2=6$ menit dan $\mathrm{H} 3=8$ menit. Kombinasi perlakuan dalam penelitian ini adalah: $6 \times 3=18$ dengan menggunakan 2 (dua) kali ulangan sehingga diperoleh 36 satuan percobaan.

\section{Prosedur Percobaan}

\section{Persiapan Bahan Baku}

Sampel buah segar kopi arabika (buah ceri merah) diperoleh dari petani di Kabupaten Aceh Tengah. Buah kopi diperoleh dari hasil panen petani disortasi dengan cara manual yang bertujuan untuk memisahkan buah muda dan benda asing lainnya. Selanjutnya dilakukan penggilingan buah kopi dengan mesin pulper yang bertujuan untuk memisahkan biji kopi dan kulit buah (pulp). Pulp yang diperoleh selanjutnya dikumpulkan dan siap digunakan untuk pembuatan cascara (hanya untuk bahan baku perlakuan P1, P2 dan P3). Khusus untuk perlakuan P4, tidak dilakukan pemisahan kulit (tidak ikut di pulping), buah kopi segar langsung dijemur hingga kering (cara kering atau natural). Untuk perlakuan P5 (pulp kering dari wine kopi), prosesnya sedikit mirip dengan P4 namun petani secara khusus melakukan fermentasi dan penjemuran dalam waktu yang lebih lama. Pada perlakuan 6, 
persiapan bahan baku dilakukan dengan mengambil langsung pulp segar dari petani kopi di Aceh Tengah.

\section{Pembuatan Cascara (Modifikasi Umanzor, 2017)}

Pulp yang diperoleh dari mesin pulper kopi ditimbang masing-masing $1 \mathrm{~kg}$ dan dipisahkan sesuai dengan beberapa variasi kondisi yang akan dilakukan. Pada perlakuan P1, pulp kopi difermentasi dalam karung selama 12 jam, P2 pulp kopi direndam air selama 12 jam, P3 pulp kopi dibiarkan terbuka diruangan, ketiga hasil pulp yang diperoleh selanjutnya dijemur hingga kadar air sekitar 12\% (sekitar 4 hari ditandai dengan karakteristik mudah dipatahkan).

Pada perlakuan P4 (pulp dari pengolahan natural), pengambilan pulp dilakukan dengan melepaskan pulp kering secara manual. Pulp yang dihasilkan merupakan cascara siap pakai. Selanjutnya pada perlakuan P5, pulp kering dari limbah wine coffee diperoleh dari pabrik dan hanya perlu memisahkan dengan kotoran dan benda-benda asing saja, kulit kering yang sudah dipilih merupakan cascara siap pakai. Untuk perlakuan P6, pulp yang diambil dari limbah petani berupa pulp segar langsung dijemur sampai kadar air sekitar 12\%. Hasil cascara dari keenam perlakuan ini kemudian disimpan dalam wadah gelas bertutup rapat yang telah diberi kode, hingga siap digunakan untuk penyeduhan cascara selanjutnya.

\section{Penyeduhan cascara}

Cascara yang diperoleh dari masing-masing variasi kondisi perlakuan ditimbang sebanyak 25 gram dan ditambahkan air panas bersuhu $90{ }^{\circ} \mathrm{C}$ sebanyak $450 \mathrm{ml}$. Penyeduhan Cascara dilakukan dengan waktu sesuai perlakuan yaitu $\mathrm{H} 1=4$ Menit, $\mathrm{H} 2=6$ Menit, $\mathrm{H} 3=8$ Menit. Cascara disaring kemudian diambil hasil seduhannya dan didiamkan \pm 7 menit untuk memperoleh keseragaman suhu.

\section{Analisis Data}

Hasil seduhan cascara selanjutnya dianalisis secara kimia dan sensori. Analisis kimia yang dilakukan meliputi analisis pH (AOAC, 2000), total padatan terlarut (Ismawati et al., 2016) dan uji total fenol (Prima et al., 2008). Data hasil pengamatan dianalisis dengan ANOVA, uji lanjut dilakukan dengan uji DMRT pada taraf 0,05 .

\section{HASIL DAN PEMBAHASAN}

\section{A. Nilai pH Seduhan Cascara}

Hasil analisis nilai pH cascara berkisar antara 4,31 - 5,63 dengan rata-rata 5,11. Hasil sidik ragam menunjukkan bahwa perlakuan pulp kopi $(\mathrm{P})$, lama seduhan $(\mathrm{H})$ serta interaksi keduanya berpengaruh sangat nyata $(\mathrm{P} \leq 0,01)$ terhadap nilai $\mathrm{pH}$ seduhan cascara. Pengaruh interaksi perlakuan pulp kopi $(\mathrm{P})$ dan lama seduhan $(\mathrm{H})$ terhadap nilai $\mathrm{pH}$ dapat dilihat pada Gambar 1 .

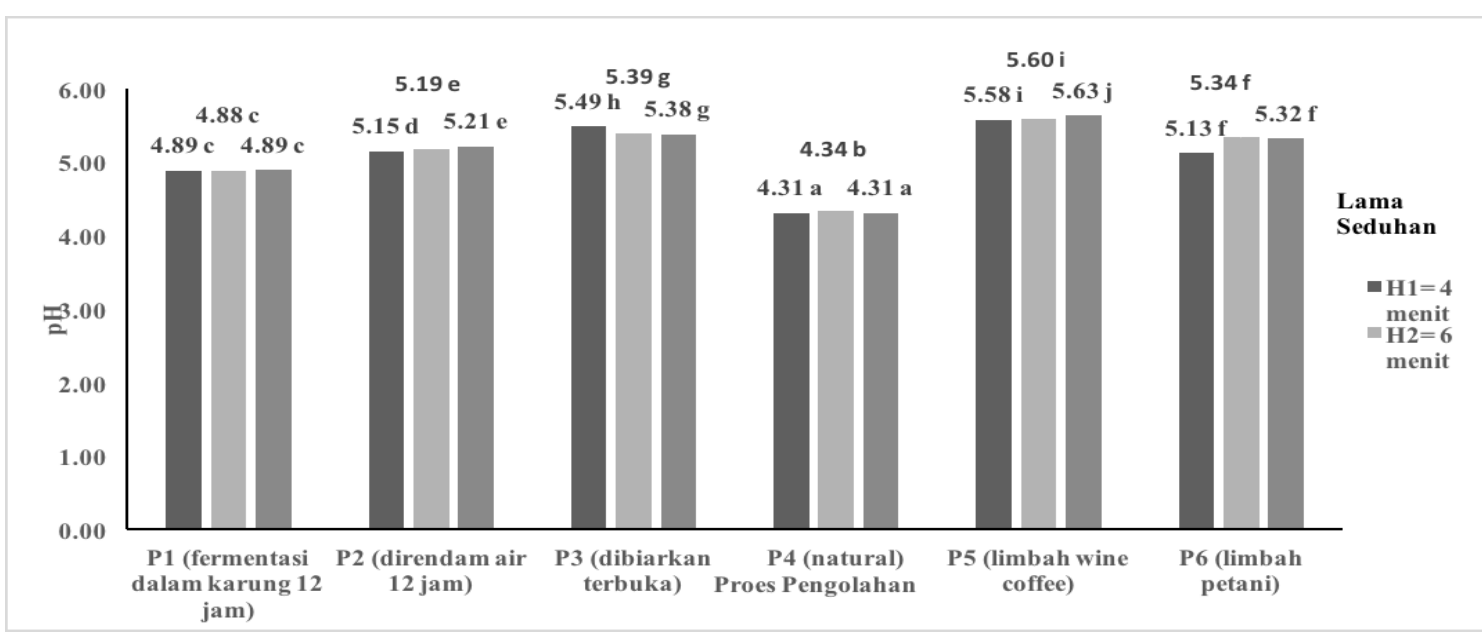

Gambar 1. Pengaruh interaksi perlakuan pulp kopi $(\mathrm{P})$ dan lama seduhan $(\mathrm{H})$ terhadap nilai $\mathrm{pH}$ seduhan cascara (nilai-nilai yang diikuti oleh huruf yang sama menunjukkan perbedaan tidak nyata, $\mathrm{DMRT}=0,11336-0,13256, \mathrm{KK}=0,612 \%$ ) 
Berdasarkan Gambar 1 terlihat bahwa nilai $\mathrm{pH}$ yang rendah secara keseluruhan diperoleh pada seduhan cascara yang dibuat dari perlakuan pulp kopi proses natural (P4) pada setiap lama seduhan yang berbeda. Nilai ini dibawah rata-rata seluruh perlakuan, yang menunjukkan bahwa lebih asam dari perlakuan lainnya. Tingkat keasaman cascara dipengaruhi oleh beberapa faktor antara lain proses pengolahan dan jenis kopi yang digunakan (Aditya, 2015). Pada penelitian ini jenis kopi yang digunakan seragam yaitu kopi arabika sehingga yang diduga mempengaruhi $\mathrm{pH}$ seduhan cascara ini adalah proses pengolahan yang berbeda.

Perlakuan pulp pada pengolahan kopi secara natural (P4) berbeda dibandingkan lainnya, dimana buah kopi yang masih segar langsung dijemur tanpa adanya pemisahan pulp. Pulp kering yang dihasilkan sebagai cascara tentunya mempunyai nutrisi yang berbeda, pulp dengan biji kopi yang masih menyatu mengandung gula yang lebih tinggi dibandingkan pulp yang dijemur terpisah dari biji kopi. Gula yang tinggi ini akan terfermentasi saat penjemuran menjadi sejumlah asam organik yang akan berpengaruh pada $\mathrm{pH}$. Semakin tinggi kadar gula yang difermentasi, semakin tinggi asam organik yang dihasilkan sehingga $\mathrm{pH}$ semakin rendah (Junior et al., 2009; Poltronieri dan Rossi, 2019).

\section{B. Total Padatan Terlarut Seduhan Cascara}

Hasil analisis nilai total padatan terlarut (TPT) seduhan cascara pada berbagai taraf perlakuan berkisar antara $0,2-0,7^{\circ}$ Brix dengan rata-rata $0,43^{\circ}$ Brix. Hasil sidik ragam menunjukkan bahwa perlakuan pulp kopi (P) dan perlakuan lama seduhan $(\mathrm{H})$ serta interaksi kedua perlakuan (PxH) berpengaruh sangat nyata $(\mathrm{P} \leq 0,01)$ terhadap nilai total padatan terlarut seduhan cascara. Pengaruh interaksi perlakuan pulp kopi $(\mathrm{P})$ dan lama seduhan $(\mathrm{H})$ terhadap nilai padatan terlarut dapat dilihat pada Gambar 2.

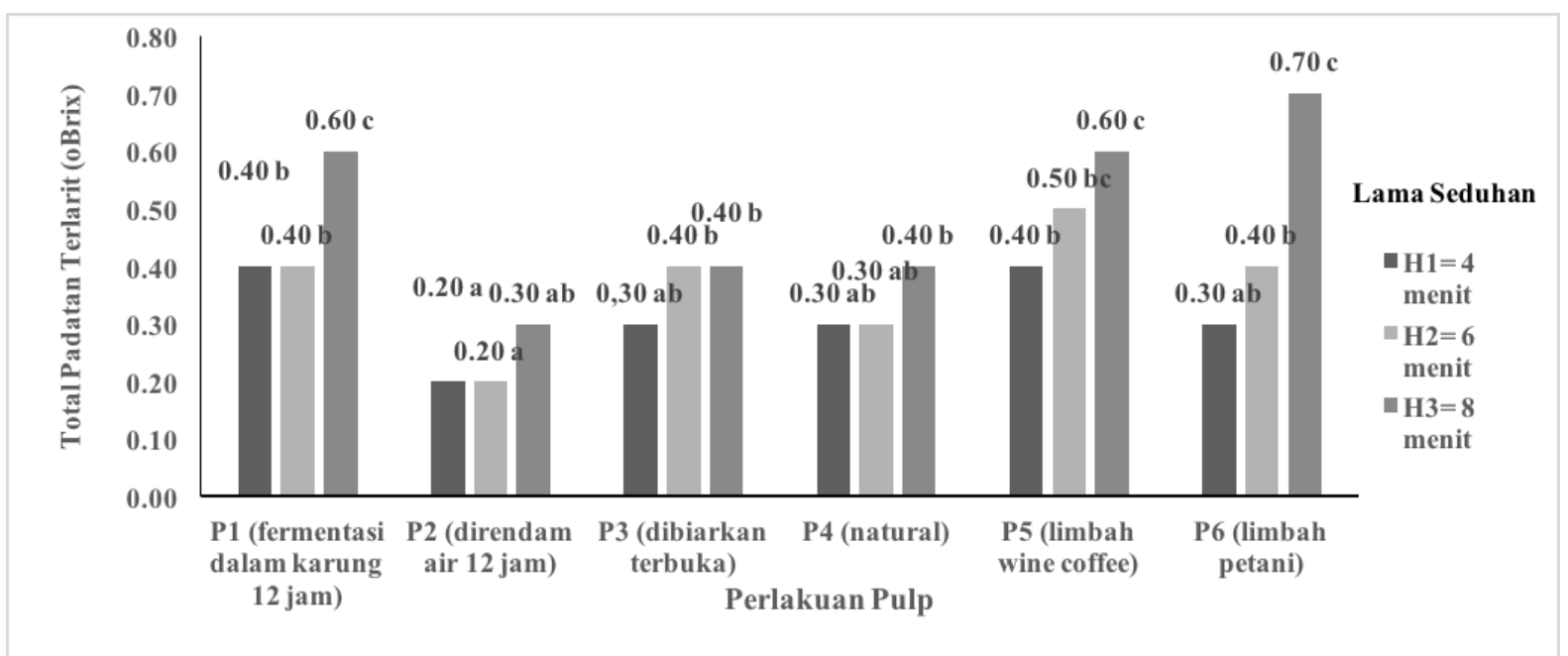

Gambar 2. Pengaruh interaksi perlakuan pulp kopi (P) dan lama seduhan (H) terhadap nilai total padatan terlarut cascara (nilai-nilai yang diikuti oleh huruf yang sama menunjukkan perbedaan tidak nyata, DMRT $=0,11336-0,13256, \mathrm{KK}=11,61 \%$ )

Berdasarkan Gambar 2 terlihat bahwa total padatan terlarut yang tinggi diperoleh pada seduhan cascara dari pulp limbah petani, pulp limbah wine kopi dan pulp hasil fermentasi dalam karung selama 12 jam dengan lama waktu penyeduhan 8 menit. Terlihat kecenderungan semakin lama waktu penyeduhan semakin tinggi TPT. TPT dapat menginterpretasikan kandungan gula yang terdapat pada seduhan cascara. Sintasari et al. (2014) mengatakan bahwa TPT dapat menginterpretasikan kandungan sisa-sisa gula hasil perombakan dari proses fermentasi.

TPT terendah diperoleh dari seduhan cascara yang diperoleh dengan merendam pulp dalam air selama $12 \mathrm{jam}$. Selain karena proses fermentasi, diduga terjadi pelarutan beberapa komponen gula sehingga TPT yang dihasilkan sangat rendah. Pada perlakuan tersebut, Pulp P6 (limbah petani) diperoleh dari lahan petani dimana pulp dibiarkan begitu saja. Hal ini menyebabkan pulp tidak mengalami fermentasi yang baik karena terkontaminasi dengan lingkungan bebas. 
Kemudian pada Gambar 8 dapat dilihat bahwa pada umumnya lama seduhan 8 menit (H3) cenderung memiliki nilai total padatan terlarut yang lebih tinggi dibanding 4 menit (H1) dan 6 menit $(\mathrm{H} 2)$. Semakin lama penyeduhan maka semakin banyak waktu air untuk mengekstrak dan melarutkan senyawa organik pada cascara. Hasil penelitian Ibrahim et al (2015) menunjukkan bahwa semakin lama proses ekstraksi maka semakin besar kadar padatan terlarut, ini diperkuat dengan pernyataan Pantastico (1986) yang menyatakan bahwa dengan peningkatan suhu dan waktu penyeduhan, total padatan terlarut akan terus meningkat hal ini disebabkan karena semakin tinggi suhu dan lama seduhan maka akan menyebabkan pemutusan rantai-rantai panjang senyawa karbohidrat menjadi senyawa gula akan semakin cepat.

\section{Total Fenol Seduhan Cascara}

Data hasil penelitian menunjukkan bahwa nilai total fenol pada berbagai taraf perlakuan berkisar antara 34,76-50,61 $\mathrm{mg}$ GAE/ml dengan rata-rata 39,60 $\mathrm{mg} \mathrm{GAE} / \mathrm{ml}$. Hasil sidik ragam menunjukkan bahwa perlakuan lama seduhan $(\mathrm{H})$ berpengaruh nyata $(\mathrm{P} \leq 0,05)$ terhadap nilai total fenol cascara, sedangkan pengaruh perlakuan pulp kopi (P) dan interaksi pulp kopi dan lama seduhan $(\mathrm{PxH})$ berpengaruh tidak nyata $(\mathrm{P}>0,05)$. Pengaruh lama seduhan $(\mathrm{H})$ terhadap nilai total fenol dapat dilihat pada Gambar 3.

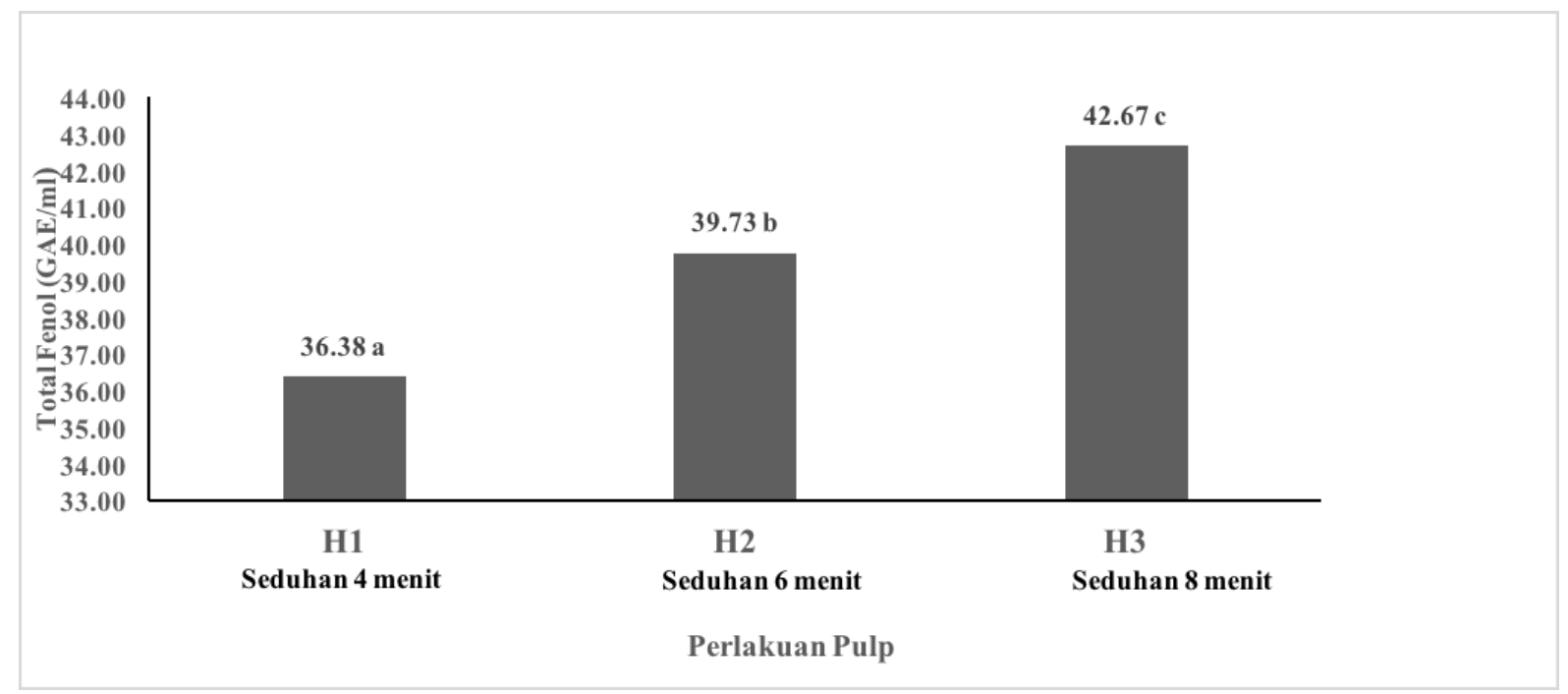

Gambar 3. Pengaruh lama seduhan (H) terhadap nilai total fenol seduhan cascara (nilai-nilai yang diikuti oleh huruf yang sama menunjukkan perbedaan tidak nyata, DMRT=0,393-1,272,

$$
\mathrm{KK}=75,3117 \%) \text {. }
$$

Gambar 3 menunjukkan nilai total fenol akibat pengaruh lama seduhan $(\mathrm{H})$ pada berbagai taraf yaitu H1 (36,38 mg GAE/ml), H2 (39,73 mg GAE/ml) dan H3 (42,67 mg GAE/ml). Hasil uji DMRT $_{0,05}$ menunjukkan nilai total fenol pada taraf perlakuan $\mathrm{H} 3$ berbeda dengan taraf lainnya dan menghasilkan nilai total fenol tertinggi. Ini dikarenakan lama seduhan mempengaruhi ekstraksinya senyawa yang terkandung pada teh seduhan cascara. Menurut Jahangiri et al., 2011, umumnya suhu dan lama seduhan berpengaruh pada kandungan total fenol. Pada proses penyeduhan suhu dan lama waktu memiliki peranan yang berpengaruh pada kandungan kimia yang terekstrak didalamnya. Semakin lama proses penyeduhan maka semakin tinggi pula kandungan yang terekstak didalamnya, waktu penyeduhan yang terlalu singkat dan suhu yang rendah akan menyebabkan sedikitnya senyawasenyawa teh yang terekstrak (Wazier, 2011; Nindyasari, 2012).

Menurut Esquivel (2011), limbah pulp kopi memiliki komposisi seperti karbohidrat (35\%), protein $(10 \%)$ dan mineral $(10,7 \%)$, protein $(8,9 \%)$, gula $(4,1 \%)$. Selain itu, limbah pulp ini mengandung senyawa polifenol (asam klorogenat, flavonol, antosianidin, katekin, rutin, tanin dan asam ferulat). Kandungan yang dominan pada pulp kopi adalah senyawa polifenol yang berpotensi sebagai sumber antioksidan. 


\section{KESIMPULAN}

Kulit buah kopi dapat dimanfaatkan untuk pembuatan cascara. Perlakuan kondisi pulp dan lama penyeduhan kulit kopi berpengaruh terhadap nilai $\mathrm{pH}$ dan TPT seduhan cascara. Nilai $\mathrm{pH}$ terendah diperoleh pada perlakuan pengolahan pulp secara natural dengan lama penyeduhan 8 menit. Nilai TPT terendah diperoleh pada perlakuan perendaman pulp dalam air. Lama penyeduhan berpengaruh terhadap total fenol yang terekstrak, semakin lama penyeduhan semakin tinggi total fenol yang dihasilkan. Cascara dengan total fenol tertinggi diperoleh pada pembuatan cascara dari pulp secara natural dengan penyeduhan 8 menit.

\section{DAFTAR PUSTAKA}

Aditya, I. W. 2015. Kajian kandungan kafein kopi bubuk, nilai pH dan karakteristik aroma dan rasa seduhan kopi jantan (pea berry coffee) dan betina (flat beans coffee) jenis arabika dan robusta. Skripsi. Fakultas Teknologi Pangan. Unversitas Udayana. Bukit Jimbaran.

AOAC. 2000. Official methode of analysis. Association of Analytical Chemist, Washington D.C.

Baggenstoss, Jürg. 2008. Coffee roasting and quecnhing technology - formation and stability of aroma compounds. Dissertation, Eidgenossische Technische Hochshule Zuerich (ETH) Switzerland.

Badan Pusat Statistik. 2016. Indonesia coffee statistic 2016. BPS Jakarta.

Berlitz, H.-D., Grosch, W., Schieberle, P., 2009. Food chemistry. Springer Berlin Heidelberg, Berlin, Heidelberg.

Direktorat Jendral Perkebunan Republik Indonesia. 2017. Buku statistik kopi. Kementrian Pertanian, Jakarta.

Esquivel, P., \& Jiménez, V. M. 2012. Functional properties of coffee and coffee by-products. Food Research International, 46(2): 488-495.

Ghani, H. 2017. Cascara, teh kulit biji kopi dari Garut yang mendunia. http://news.detik.com/beritajawa-barat/d-3606556/cascara-teh-kulit-biji-kopi

Heeger, A., A, K, Cagnazzo., Ennio, C., Wilfried, A. 2016. Bioactives of coffee cherry pulp and its utilisation for production of Cascara beverage. Siecence Research. 3: 120-127

Ibrahim, A.M., Yunianta., F.P Sriherfyna. 2015. Pengaruh suhu dan lama waktu ekstraksi terhadap sifat kimia dan fisik pada pembuatan minuman sari jahe merah (zingiber officinale var. rubrum) dengan kombinasi penambahan madu sebagai pemanis. Jurnal Pangan dan Agroindustri Vol. 3 No 2: 530-541

Jahangiri, Y., H. Ghahremani., J.A. Torghabeh., dan E.A. Salehi. 2011. Effect of temperature and slovent on the total phenolic compounds extraction from leaves of Ficus carica. Journal of Chemical and Pharmaceutical Research. 3(5): 253-259.

Junior, M.M., M. Batistote., E. Cilli., J.R. Ernandes. 2009. Sucrose fermentation by Brazilian ethanol production yeasts in media containing structurally complex nitrogen sources, J. Inst. Brew. 115, 191- 197

Mussatto, S.I., Machado, E.M.S., Martins, S., Teixeira, J.A., 2011b. Production, composition, and application of coffee and its industrial residues. Food Bioprocess Technol. 4: 661-672.

Mustika, T. 2016. Metode penyeduhan cascara. https://majalah.ottencoffee.co.id/metode-menyeduhcascara. Diakses 28 Juni 2019.

Muzaifa, M dan D. Hasni. 2015. Analisis mutu kopi arabika gayo yang diperoleh dari beberapa metode pengolahan spesialti. Laporan Penelitian Insentif Penelitian Pusat Studi, LPPM Universitas Syiah Kuala Banda Aceh.

Nindyasari, S. 2012. Pengaruh suhu dan waktu penyeduhan teh hijau (camellia sinensis) serta proses pencernaan in vitro terhadap aktivitas inhibisi lipase. Skripsi. Fakultas Teknologi Pertanian IPB, Bogor.

Pandey, A., Soccol, C. R., Nigam, P., Brand, D., Mohan, R., \& Roussos, S. (2000).Biotechnological potential of coffee pulp and coffee husk for bioprocesses.Biochemical Engineering Journal, 6(2), 153-162.

Poltronieri, P dan F. Rossi. 2019. Challenges in specialty coffee processing and quality assurance. Challenges 7 (19): 1-22. 
Jurnal Teknologi Pertanian Andalas Vol. 23, No.2, September 2019, ISSN 1410-1920, EISSN 2579-4019

Murna Muzaifa, Dian Hasni, Normalina Arpi, M. Ikhsan Sulaiman, Moh. Sahlan Limbong

Saroyo, H. 2014. Proses pengolahan biji kopi. http://caswellscoffee.com/proses-pengolahan-bijikopi/Diakses 28 Juni 2019.

Umanzor, C. 2017. Sensory characterization and analysis of tea infusions from dry coffee cheery pulp "cascara" from washed and natural processed coffee. Thesis. Universitas Studiorom Utinensis, Honduras.

Wazier, D. 2011. Antioxidant activities of different parts of Gnetum L. Journal Plant Biochemistry and Biotechnology. 20 (2):234-240.

Yuliandri, M. 2016. Teh dari ceri kopi. https://travel.kompas.com/read/2016/10/27 